medRxiv preprint doi: https://doi.org/10.1101/2021.10.31.21265703; this version posted November 6, 2021. The copyright holder for this

preprint (which was not certified by peer review) is the author/funder, who has granted medRxiv a license to display the preprint in

All rights reserved. No reuse allowed without permission.

\title{
Efficacy and safety of SOBERANA 02, a COVID-19 conjugate vaccine in heterologous
}

\section{three-dose combination}

Authors: M. Eugenia Toledo-Romani, M. Garcia-Carmenate, C. Valenzuela Silva, W. Baldoquin-Rodriguez,

M. Martínez Pérez, M. C. Rodríguez Gonzalez, B. Paredes Moreno, I. C. Mendoza Hernández,

R. González-Mujica Romero, O. Samón Tabio, P. M. Velazco Villares, J. P. Bacallao Castillo, E. Licea

Martín, M. Rodríguez Ortega, N. L. Herrera Marrero, E. Caballero Gonzalez, L. I. Egües Torres, R. Duarte

González, S. García Blanco, S. Pérez Cabrera, S. Huete Ferreira, K. Idalmis Cisnero, O. Fonte Galindo, D.

Meliá Pérez, I. Rojas Remedios, S. Fernandez Castillo, Y. Climent Ruiz, Y. Valdes-Balbin, D. Garcia-Rivera, V. Verez Bencomo and the SOBERANA Phase 3 team.

Affiliations: Finlay Vaccine Institute, Havana (M. M. P, M. C. R. G., B. P. M., R. G.M. R., E. L. M., E.C.G., S. F., Y. C., Y. V.B., D. G.R., V. V. B.); Pedro Kourí Tropical Medicine Institute, Havana (M. E. T.R., W. B., M. R. O., N. L. H. M.); Havana Province Hygiene and Epidemiology Center (M.G.C, L. I. E. T., R. D. G., S. G. B., S. P. C., S. H. F., K. I. C., O. F. G., D. M. P., I. R. R); Cybernetics, Mathematics and Physics Institute, Havana (C.V.S); National Clinical Trials Coordinating Center, Havana (I. C. M. H.); José Antonio Echevarría Technological University, Havana (O.S.T); and UCT Geocuba Research and Consulting, Havana (P. M. V.V., J. P. B. C.)

Abstract (word count 250), main (word count 2697) 1Table, 4 Figures. 
medRxiv preprint doi: https://doi.org/10.1101/2021.10.31.21265703; this version posted November 6, 2021. The copyright holder for this preprint (which was not certified by peer review) is the author/funder, who has granted medRxiv a license to display the preprint in

All rights reserved. No reuse allowed without permission.

\begin{abstract}
Background: SOBERANA 02 is a COVID-19 conjugate vaccine (recombinant RBD conjugated to tetanus toxoid). Phase 1 and 2 clinical trials demonstrated its high immunogenicity, promoting neutralizing IgG and specific T-cell response. A third dose, of SOBERANA Plus (RBD-dimer), further increased the specific anti-RBD neutralizing antibodies.
\end{abstract}

Methods: In a randomized, double-blind, placebo-controlled, phase-3 trial (https://rpcec.sld.cu/trials/RPCEC00000354-En) we randomly assigned 44031 participants, aged 19-80 years to three groups to receive a) two doses, SOBERANA 02, or b) two doses, SOBERANA 02 and a third dose, SOBERANA Plus, or c) placebo. Study endpoints are vaccine efficacy (VE) evaluated through confirmed symptomatic COVID-19 and safety. During the trial, the SARS CoV-2 isolates in Havana were $74.0 \% \beta$, shifting gradually to $100 \% \delta$.

Results: Two doses of SOBERANA 02 protected against symptomatic COVID-19: 43 cases in the two-dose group (14 371) vs. 155 in the placebo group (14 403), VE 71.0\%, adjusted (CI 95\%, 58.9-79.1). The heterologous three-dose combination increased the protection: 15 cases in the vaccine groups (13 833) vs. 155 in the placebo group (14 303), VE 92.4\%, adjusted (CI 95\%, 86.9-95.6\%). For the two-dose schedule, VE against severe COVID-19 was $63.0 \%$ and for death, $59.0 \%$; for the heterologous three-dose schedule, VE was $100 \%$ in both cases.

Conclusions: This is the first phase- 3 study of a three-dose, heterologous COVID-19 vaccine. Two doses of SOBERANA 02 were safe and attained efficacy of $71.0 \%$ in the adult population 19-80 y/o; incorporating SOBERANA Plus increased efficacy from 71.0 $\%$ to $92.4 \%$. 
medRxiv preprint doi: https://doi.org/10.1101/2021.10.31.21265703; this version posted November 6, 2021. The copyright holder for this preprint (which was not certified by peer review) is the author/funder, who has granted medRxiv a license to display the preprint in

All rights reserved. No reuse allowed without permission.

\section{Introduction}

Vaccination represents the main tool in the fight against COVID-19 pandemic. Vaccination speed is critical to control the emergency and the spread of new virus variants. [1]

SOBERANA 02 is the first conjugated vaccine developed for SARS CoV-2. The antigen is the recombinant receptor binding domain (RBD) protein conjugated chemically to tetanus toxoid (TT) in a molar ratio 6/1.[2] The development of protein-polysaccharide conjugation technology in the 1980s furnished safe, highly immunogenic novel pediatric vaccines against Haemophilus influenzae type b [3]. Other conjugate vaccines based on carbohydrate antigens are in use in the pediatric population for Neisseria meningitidis and Streptococcus pneumoniae $[4,5,6,7]$. None is for SARS CoV-2 prevention.

A single dose of SOBERANA Plus is an excellent booster of natural immunity in convalescent COVID-19 patients[8] through a mechanism called hybrid immunity [9]. In phase 1 and 2a clinical trials, two doses of SOBERANA 02 induced neutralizing antibodies and B and T-cell memory with a typical IFN $\gamma$ secretion, Th1 pattern.[10] SOBERANA Plus — as a third dose — significantly increased neutralizing anti-RBD IgG. These results were confirmed in a phase $2 \mathrm{~b}$ clinical trial, paving the way to launch the phase 3 trial. This phase 3 trial (IFV/COR/09 number, RPCEC00000354) evaluates the safety and efficacy of two immunization regimes: a) two doses of SOBERANA 02 and b) its heterologous combination with SOBERANA Plus as the third dose. These are the results of the final analyses.

\section{Methods}

\section{Study Design, Oversight and Ethics}

A double-blind, randomized, placebo-controlled, stratified, case-driven phase 3 clinical trial recruited adult participants in medically stable condition from 48 sites in eight Havana municipalities. Participants recruited March 8-31, 2021 by community family doctors provided written informed consent. The trial adheres to the principles of the Helsinki Declaration and to the International Council for Harmonization's Good Clinical Practice guidelines. The Cuban Ministry of Health's Central Research Ethics Committee was appointed ad hoc for this trial. It approved the protocol (Clinical Trials IFV/COR/09 
medRxiv preprint doi: https://doi.org/10.1101/2021.10.31.21265703; this version posted November 6, 2021. The copyright holder for this preprint (which was not certified by peer review) is the author/funder, who has granted medRxiv a license to display the preprint in

All rights reserved. No reuse allowed without permission.

number, RPCEC00000354) and the consent forms. (Details on procedures are provided in the protocol and Supplementary Information (SI) available upon publication).

The Cuban National Clinical Trials Coordinating Center (CENCEC) monitored the trial in terms of adherence to the protocol and Good Clinical Practice as well as data accuracy. An unblinded independent data and safety monitoring board (IDSMB) continuously monitored safety and conducted interim analysis (IA). The trial was designed, conducted and sponsored by the Finlay Vaccine Institute. Data analysis and interpretation were performed by the research team. The SOBERANA 02 team collected data and contributed to their interpretation.

\section{Participants, randomization and data blinding}

Volunteers aged 19-80 years were screened for eligibility at clinical sites. A full list of exclusion criteria is provided with the study protocol available upon publication. Three groups were formed to receive two doses of SOBERANA 02 (group A); two doses of SOBERANA 02 followed by a third dose of SOBERANA Plus (heterologous scheme, group B); and placebo (two doses) administered 28 days apart. Randomization into study $\operatorname{arms}(\mathrm{A}$ and $\mathrm{B})$ and placebo was done on day 0 at a 1:1:1 ratio using a site stratified random and previously defined risk strata (19-64 years without risk comorbidities, 19-64 years with risk comorbidities and $\geq 65$ years). Participants at risk of severe COVID-19 disease were defined in the protocol available upon publication. In the event of a medical emergency requiring acute intervention, unmasking was planned after approval by the responsible investigator and IDSMB knowledge.

\section{Trial vaccines/placebo}

SOBERANA 02 antigen is the recombinant SARS-CoV-2 RBD $(25 \mu \mathrm{g})$, chemically conjugated to TT in a molar ratio $\sim 6 / 1$ and adsorbed on $500 \mu \mathrm{g}$ alumina [2]. SOBERANA Plus was develop as a universal booster; the antigen is dimeric RBD $(50 \mu \mathrm{g})$ adsorbed on $1250 \mu \mathrm{g}$ alumina [11]. The placebo contained all ingredients except the active principle.

Vaccine and placebo were indistinguishable to ensure product masking. Both were stored at $2^{\circ}$ to $8^{\circ} \mathrm{C}$ and distributed daily to clinical sites by specialized logistics personnel.

\section{Safety}


medRxiv preprint doi: https://doi.org/10.1101/2021.10.31.21265703; this version posted November 6, 2021. The copyright holder for this preprint (which was not certified by peer review) is the author/funder, who has granted medRxiv a license to display the preprint in

All rights reserved. No reuse allowed without permission.

AEs were classified as solicited and unsolicited; as mild, moderate and severe; and vaccine related or non-related. Frequencies were calculated after each vaccine/placebo dose: solicited local and systemic, during 7 days; unsolicited, during 28 days; leading to protocol discontinuation, demanding medical attention or classified as serious, during 30 days. IDSMB continuously monitored COVID-19 and severe COVID-19 cases. Safety was evaluated in the "Safety Population"(SP): participants receiving at least one dose of the vaccine candidates or placebo.

\section{Efficacy}

The primary endpoint was VE in preventing occurrence of symptomatic COVID-19 confirmed by positive SARS-CoV-2 RT-PCR nasopharyngeal swab (RT-PCR), with onset at least 14 days after the last injection in the per-protocol population (PPP). Primary endpoint was judged blinded by COVID-19 hospital doctors, reviewed by specially trained doctors and finally by the study's Principal Investigator (PI).

COVID-19 symptomatic disease was considered if participants had at least one major symptom or sign or two minor symptoms (major signs or symptoms: dyspnea, oxygen saturation $\leq 92 \%$, persistent thoracic pain, neurological disorders, clinical or radiographic evidence of pneumonia; minor symptoms: fever, chills, myalgia, headache, sore throat, running nose, diarrhea/vomiting, myalgia, malaise, cough, dysgeusia/anosmia). RT-PCR was conducted by the SARS CoV-2 national reference laboratory at the Pedro Kourí Tropical Medical Institute, Havana, Cuba. Participants with symptoms or reporting direct contact with a positive RT-PCR person were referred to a COVID-19 hospital designated by the Ministry of Public Health and advised to show their "study identity card". After a positive RT-PCR, they were hospitalized and followed daily to assess symptom severity, until hospital discharge upon negative RT-PCR and symptom resolution.

$\mathrm{VE}$ at the primary endpoint was evaluated across risk strata for severe disease (19-64 years without risk comorbidities; $19-64$ years with risk comorbidities; and $\geq 65$ years), sex (female/male), and skin color (white, black and mixed-race). Secondary outcomes for VE were severe systemic confirmed COVID-19 disease (serious or critical), defined by one of the following criteria: polypnea; $x$-ray infiltration/condensation, pulmonary echography; oxygen saturation $\leq 90 \%$ or assisted mechanical ventilation (serious disease), acute 
medRxiv preprint doi: https://doi.org/10.1101/2021.10.31.21265703; this version posted November 6, 2021. The copyright holder for this preprint (which was not certified by peer review) is the author/funder, who has granted medRxiv a license to display the preprint in

All rights reserved. No reuse allowed without permission.

respiratory distress syndrome or evidence of septic shock (critical disease). (Other secondary outcomes are included in SI upon publication).

\section{Statistical analysis}

To evaluate the primary VE endpoint, the trial was designed with the hypothesis that the risk of symptomatic disease is reduced $>60 \%$ compared to placebo group. The lower limit of the $95 \%$ confidence interval (CI) was $\geq 30 \%$, which points to the rejection of the null hypothesis (that the efficacy of either vaccination scheme is $\leq 30 \%$ )[12]. VE was calculated as percentage reduction in the hazard ratio $(\mathrm{HR})$ as $\mathrm{VE}=100 \times(1-\mathrm{HR}) \%$, in the vaccine groups as compared with placebo, separately, with HR estimated from a stratified Cox proportional hazards model. The design required achieving 90\% power (and 2.5\% 1-sided type I error) to detect a HR of 0.4 (VE $>60 \%$ to reduce the risk of symptomatic disease compared to placebo), with a null hypothesis HR of 0.7 . VE bounds were derived using a Lan-DeMets O'Brien-Fleming approximation spending function. Two interim analyses (IA) were planned at detection of 53 and 106 symptomatic cases meeting the primary outcome definition more than 14 days after the last dose of the corresponding schedule.

A stopping criterion due to unacceptable toxicity (frequency $>1 \%$ ) was evaluated iteratively, with a Bayesian algorithm (SI upon publication).

\section{Results}

\section{Trial Population}

Recruited participants (44 031) underwent randomization (mean age: 48 years, 52\% female, $18 \% \geq 65$ years, 28\% 19-64 years with comorbidities) as follows: group A: 14679 (two doses, SOBERANA 02), group B: 14677 (three doses heterologous schedule) and group C: 14675 (placebo) (Fig. 1). Demographic characteristics were balanced between placebo and intervention groups (Table 1). The racial or ethnic proportions were representative of Cuban demographics. Evidence of previous SARS-CoV-2 infection at baseline as detected by serologic rapid test was present in $0.4 \%$ of participants.

173 participants withdrew consent and did not receive the second dose and 286 did not receive the third dose. Participants were excluded when detected positive by RT-PCR before receiving the second dose (407 participants) and before the third dose (123 participants). Primary efficacy and safety were analyzed in PPP and SP respectively. The 
medRxiv preprint doi: https://doi.org/10.1101/2021.10.31.21265703; this version posted November 6, 2021. The copyright holder for this preprint (which was not certified by peer review) is the author/funder, who has granted medRxiv a license to display the preprint in

All rights reserved. No reuse allowed without permission.

primary VE analysis included 42557 participants receiving the first injection: group C (placebo) (14 303), group A (14 371) and group B (13 883); 1474 participants were excluded from the PPP (Fig. 1): placebo group (372), group A (308) and group B (794). Median follow-up was 50 days (range, 0-156) and 121 days (range, 0-136) after the third dose.

\section{Safety}

Solicited AEs at injection site occurred more frequently in the vaccine group than in the placebo group after both the first dose (7.7\%, vs. $2.6 \%)$ and the second dose (1.9\%, vs. $0.44 \%$ ) (Fig. 2). After the third dose, frequency of subjects with AEs at injection site was $0.3 \%$. In the vaccine groups $(A+B)$, injection site events were predominantly grade 1 in severity and lasted a median of 1 day after the first and second dose, and 2 days after the third dose. The most common injection site AE was pain after injection ( $2.6 \%$ vs. $8.2 \%$ in placebo and vaccine, respectively at any time). Delayed injection site reactions were noted in 21 participants $(0.05 \%)$ after the first dose, $5(0.01 \%)$ after the second dose and 1 after the third dose $(0.01 \%)$. Reactions were characterized by erythema, induration, and warmth, swelling and pain, and all resolved over the following day (IQR percentiles 25-75: (0.5-2)) Solicited systemic AEs occurred more often in the vaccine groups than in the placebo group after both the first dose $(2.0 \%$ vs. $1.6 \%)$ and the second dose $(0.8 \%$ vs. $0.2 \%)$ and were $0.1 \%$ after the third dose. Their severity in the vaccine groups changed slightly; for grade 2 events, from $6.5 \%$ after the first dose to $8.8 \%$ after the second dose; for grade 3 , from $0.6 \%$ to $0.4 \%$. Solicited systemic AEs in the vaccine groups lasted a median of 1 day after the first and second doses, and 2 days after the third dose.

Both solicited injection-site (7.1\% vs. 5.1\%) and systemic AEs (2.4\% vs. $2.2 \%)$ were more common among younger participants (19-64 years) than in those $\geq 65$ years. group. AE frequency reported during the 28 days following each injection was similar in all groups: grade 3 AEs in the placebo group (3.8\%), in the vaccine groups $(3.4 \%$ and $4.2 \%$, for groups $\mathrm{A}$ and $\mathrm{B}$, respectively) and serious AEs (7.9\%, 6.7\% and 6.7\% in placebo, A and B groups respectively).

All-cause mortality was unbalanced, 9 and $11(0.1 \%$ for group A and B, among vaccine recipients) and $24(0.2 \%)$ in placebo recipients.

\section{Efficacy}


medRxiv preprint doi: https://doi.org/10.1101/2021.10.31.21265703; this version posted November 6, 2021. The copyright holder for this preprint (which was not certified by peer review) is the author/funder, who has granted medRxiv a license to display the preprint in

All rights reserved. No reuse allowed without permission.

The final analysis of the two-dose schedule detected 198 cases of COVID-19: 43 in vaccine group A (0.8 per 1000 person-years; $95 \% \mathrm{CI}, 0.6-1.1)$ and 155 in the placebo group (2.7 per 1000 person-years; 95\% CI, 2.3-3.2), indicating 71.0\% VE (95\% CI, 58.9$79.1 \% ; \mathrm{P}<0.001$ ) for prevention of symptomatic SARS-CoV-2 infection as compared to placebo (Fig. 4A).

The final analysis of the three-dose schedule registered 170 cases of COVID-19: 15 cases in vaccine group B, (0.1 per 1000 person-years; $95 \%$ CI, 0.1 to 0.1$)$ and 155 cases in the placebo group, indicating 92.4\% VE (95\% CI, 86.9-95.6\%; P<0.001) for prevention of symptomatic SARS-CoV-2 infection as compared to placebo (Fig. 4B).

For the two-dose schedule, VE for prevention of severe COVID-19 was 63.0\% (2/14731 cases in group A vs 6/14303 cases in placebo), and for heterologous three-dose schedule, $100 \%(0 / 13883$ cases in group B vs 6/14303 cases in placebo). VE for prevention of COVID-19 death was $59.0 \%$ for the two-dose schedule (3/14731 cases in group A vs $8 / 14303$ cases in placebo) and $100 \%$ for heterologous three-dose schedule $(0 / 13883$ cases in group B vs 8/14303 cases in placebo).

\section{Discussion}

SOBERANA 02 conjugate vaccine is a safe and efficacious vaccine for prevention of symptomatic COVID-19 in the adult population aged 19-80 years. The trial was planned for measuring $>60 \%$ expected efficacy by protocol at a time when the original SARS CoV2 strain was predominant in Havana, the trial site. In fact, the two-dose VE of $62 \%$ was attained in the IA during predominant transmission of $\beta$ VOC (74\% of isolates in Havana) carrying the E484K mutation that substantially reduces its neutralization by antibodies in sera of convalescent and vaccinated persons.[13] At the final analysis, a shift from $\beta$ VOC to $\delta$ VOC was already apparent in Havana.[14] A higher two-dose VE of 71\% was obtained for prevention of symptomatic disease. The heterologous third dose of SOBERANA Plus showed $91.2 \% \mathrm{VE}$ at IA, which slightly increased to $92.4 \%$ at final analysis. It is noteworthy that VE was invariably high independently of the circulating VOC. A very favorable safety profile was revealed within a median safety follow-up of $\sim 2$ months after full vaccination. It was characterized by mild, transient, local reactogenicity and absence of serious vaccine-related AEs. Unlike other vaccines, systemic AEs were not 
medRxiv preprint doi: https://doi.org/10.1101/2021.10.31.21265703; this version posted November 6, 2021. The copyright holder for this

preprint (which was not certified by peer review) is the author/funder, who has granted medRxiv a license to display the preprint in

All rights reserved. No reuse allowed without permission.

predominant. Noteworthy is the fact that local AEs reported substantially reduced for the third dose (SOBERANA Plus). This vaccine was previously evaluated in SARS CoV-2 convalescents. [8] The remarkable safety profile and the increased efficacy attained here confirm its potential as a universal booster; it was highly efficient in preventing severe disease and death, attaining $100 \%$.

In this study, final VE was computed 14 days after the last immunization; that is, for participants receiving the three-dose heterologous schedule, on day 70 post first immunization. The main limitation of this study - as of most phase 3, COVID-19 VE studies - is the narrow time window for VE evaluation. Immunity's waning over time and its impact on efficacy are key aspects that deserve priority attention. Currently, we are following protection evolution over time, as well as vaccine behavior towards new circulating variants; these aspects will be addressed in forthcoming papers.

In conclusion, the conjugate vaccine SOBERANA 02 was efficacious and induced crossprotection during a dominant circulation of the VOC $\beta$ and VOC $\delta$. The third heterologous dose of SOBERANA Plus increased efficacy to an outstanding $92.4 \%$ for prevention of severe disease.

Taken together, our findings indicate that SOBERANA 02 is a promising vaccine that can be used in a two-dose regime or in heterologous three-dose combination with SOBERANA Plus to address the COVID-19 pandemic in the adult population. Its safety profile and efficacy also suggest potential for use in pediatric age groups. 
medRxiv preprint doi: https://doi.org/10.1101/2021.10.31.21265703; this version posted November 6, 2021. The copyright holder for this preprint (which was not certified by peer review) is the author/funder, who has granted medRxiv a license to display the preprint in

All rights reserved. No reuse allowed without permission.

\section{[Disclosures]}

Supported by the Finlay Vaccine Institute, BioCubaFarma and the Fondo Nacional de Ciencia y Técnica (FONCI-CITMA-Cuba, contract 2020-20).

Disclosure forms provided by the authors are available with the full text of this article upon publication.

A data sharing statement provided by the authors is available with the full text of this article upon publication.

\section{[Acknowledgments]}

We especially thank all the volunteers who participated in the trial and the members of the SOBERANAPhase 3 clinical trial team (listed in the Supplementary Information upon publication) for their dedication and contributions to the trial.

We also thank IDSMB members: N. A. Jimenez Perez (Chair and Clinical Expert) and C. M. Fonseca Gómez (Clinical Expert) from Pedro Kourí Tropical Medicine Institute, G. María Suárez Formigo (Immunologist Expert) and P. Lorenzo-Luaces Alvarez (Statistic Expert) from Center for Molecular Immunology, M. Martínez Cabrera (Clinical Expert) from the Ministry of Public Health.

We also thank Rolando Pérez, Ileana Morales, and Eduardo Martínez (BioCubaFarma), for their advice and support, and Lila Castellanos for scientific advice and corrections.

\section{References}

\footnotetext{
${ }^{1}$ P. R. Krause, T.R. Fleming, I. M. Longini, R. Peto, S.Briand, D.L. Heymann, et al., SARS-CoV-2 Variants and Vaccines, N Engl J Med 2021; 385:179-186

${ }^{2}$ Y. Valdes-Balbin et al., SARS-CoV-2 RBD-Tetanus Toxoid Conjugate Vaccine Induces a

Strong Neutralizing Immunity in Preclinical Studies, ACS Chem. Biol. 2021, 16, 7, 1223-1233, https://doi.org/10.1101/2021.02.08.430146.

${ }^{3}$ Schneerson R, et al. Haemophilus influenzae type B polysaccharide-protein conjugates: Model for a new generation of capsular polysaccharide vaccines. Prog Clin Biol Res 1980, 47, 77-94

${ }^{4}$ Astronomo RD, Burton DR. Carbohydrate vaccines: developing sweet solutions to sticky situations? Nat Rev Drug Discov. 2010;9(4):308-24.

${ }^{5}$ Costantino $P$, Rappuoli R, Berti F. The design of semi-synthetic and synthetic glycoconjugate vaccines. Expert Opin Drug Discov. 2011;6(10):1045-66.

${ }^{6}$ R. Mettu, Ch.-Yun Chen, Ch.-Yi Wu, Synthetic carbohydrate-based vaccines: challenges and opportunities, Journal of Biomedical Science (2020) 27:9

${ }^{7}$ Goldblatt D. The indirect effect of pneumococcal conjugate vaccine. Lancet Glob Health. 2017;5(1):e6-7.

${ }^{8}$ A. Chang-Monteagudo, R. Ochoa-Azze, Yanet Climent-Ruiz et al. A single dose of SARS-CoV-2 FINLAY-FR-1A vaccine enhances neutralization response in COVID-19 convalescents, with a very good safety profile: An open-label phase 1 clinical trial, The Lancet Regional Health-Americas, https://doi.org/10.1016/j.lana.2021.100079

${ }^{9}$ Y. Chen, P. Tong, N. B. Whiteman et al., Differential antibody dynamics to SARS-CoV-2 infection and vaccination, bioRxiv preprint doi: https://doi.org/10.1101/2021.09.09.459504

${ }^{10}$ Maria E. Toledo-Romani et al., Safety and Immunogenicity of anti-SARS CoV-2 vaccine SOBERANA 02 in homologous or heterologous scheme, Vaccine, Submitted
} 
medRxiv preprint doi: https://doi.org/10.1101/2021.10.31.21265703; this version posted November 6 , 2021. The copyright holder for this preprint (which was not certified by peer review) is the author/funder, who has granted medRxiv a license to display the preprint in All rights reserved. No reuse allowed without permission.

${ }^{11}$ D. Santana-Mederos et al., A COVID-19 vaccine candidate composed of SARS-CoV-2 RBD dimer and Neisseria meningitidis outer membrane vesicles, RSC Chemical Biology, Submitted

${ }^{12}$ WHO consideration for an evaluation of COVID19 Vaccines. Point to consider for manufacturers of COVID 19 vaccines, Sept 2020

${ }^{13} \mathrm{~S}$. Jangra et al., SARS-CoV-2 spike E484K mutation reduces antibody neutralization, The Lancet, Microbe, 2021, e284, https://doi.org/10.1016/ S2666-5247(21)00068-9

${ }^{14} \mathrm{G}$. Guzman et al., updated report of the "Pedro Kouri"Tropical Medicine Institute on the circulating strains of SARS COVID19 in Havana, personal communication. 


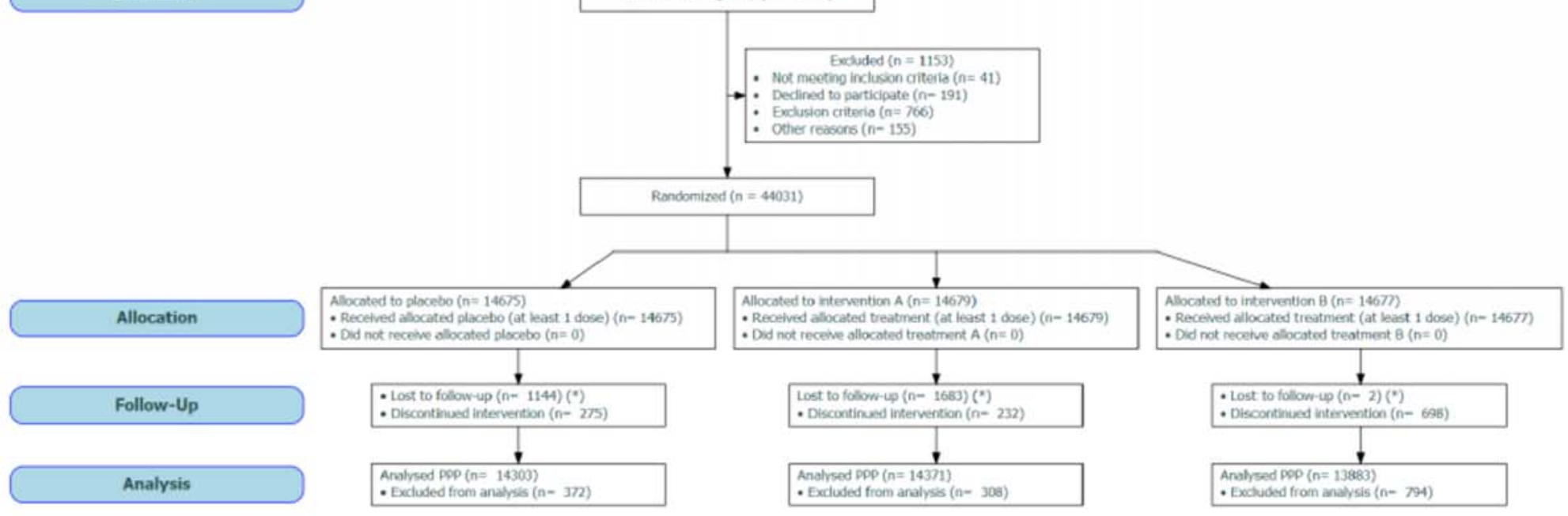


medRxiv preprint doi: https://doi.org/10.1101/2021.10.31.21265703; this version posted November 6, 2021. The copyright holder for this preprint (which was not certified by peer review) is the author/funder, who has granted medRxiv a license to display the preprint in perpetuity.

All rights reserved. No reuse allowed without permission.

Table 1. Demographics and clinical characteristics at baseline.

\begin{tabular}{|c|c|c|c|c|}
\hline \multirow[b]{2}{*}{ Characteristic } & \multirow[b]{2}{*}{$\begin{array}{c}\text { Overall } \\
\mathrm{N}=44,031^{1}\end{array}$} & \multicolumn{3}{|c|}{ Treatment $\S$} \\
\hline & & $\begin{array}{c}\text { Placebo } \\
\mathrm{N}=14,675^{1}\end{array}$ & $\begin{array}{c}\text { Group A } \\
N=14,679^{1}\end{array}$ & $\begin{array}{c}\text { Group B } \\
\mathrm{N}=14,677^{1}\end{array}$ \\
\hline Age - Mean (range) - years & $48(18-81)$ & $48(18-81)$ & $48(18-81)$ & $49(18-81)$ \\
\hline \multicolumn{5}{|l|}{ Race or ethnic group - $\mathrm{n}(\%)$} \\
\hline Black & $7,276(17)$ & $2,453(17)$ & $2,379(16)$ & $2,444(17)$ \\
\hline Mixed-race & $10,738(24)$ & $3,574(24)$ & $3,575(24)$ & $3,589(24)$ \\
\hline White & $26,017(59)$ & $8,648(59)$ & $8,725(59)$ & 8,644 (59) \\
\hline \multicolumn{5}{|l|}{ Sex - $n(\%)$} \\
\hline $\mathrm{F}$ & $23,102(52)$ & $7,662(52)$ & $7,694(52)$ & $7,746(53)$ \\
\hline$M$ & $20,929(48)$ & $7,013(48)$ & $6,985(48)$ & $6,931(47)$ \\
\hline Comorbidities - n (\%)* & $18,074(41)$ & $5,968(41)$ & $6,064(41)$ & $6,042(41)$ \\
\hline Asthma - n(\%) & $2,926(6.6)$ & $994(6.8)$ & $945(6.4)$ & $987(6.7)$ \\
\hline COPD - n (\%) & $311(0.7)$ & $95(0.6)$ & $104(0.7)$ & $112(0.8)$ \\
\hline Cancer - n (\%) & $263(0.6)$ & $96(0.7)$ & $79(0.5)$ & $88(0.6)$ \\
\hline Obesity - n(\%) & $1,772(4.0)$ & $592(4.0)$ & 577 (3.9) & $603(4.1)$ \\
\hline Cardiovascular disease $\mathrm{n}(\%)$ & $1,336(3.0)$ & 454 (3.1) & $430(2.9)$ & $452(3.1)$ \\
\hline Diabetes mellitus n(\%) & $3,673(8.3)$ & $1,194(8.1)$ & $1,224(8.3)$ & $1,255(8.6)$ \\
\hline CKD n(\%) & $111(0.3)$ & $40(0.3)$ & $36(0.2)$ & $35(0.2)$ \\
\hline Immunodeficiency - n(\%) & $2,636(6.0)$ & $870(5.9)$ & $872(5.9)$ & $894(6.1)$ \\
\hline HBP- n (\%) & $13,703(31)$ & $4,529(31)$ & $4,572(31)$ & $4,602(31)$ \\
\hline Severe malnutrition $\mathrm{n}(\%)$ & $354(0.8)$ & $120(0.8)$ & $128(0.9)$ & $106(0.7)$ \\
\hline \multicolumn{5}{|c|}{ Age category and risk for severe Covid-19 (strata) - n (\%) } \\
\hline$\geq 65$ years & $7,908(18)$ & $2,634(18)$ & $2,639(18)$ & $2,635(18)$ \\
\hline $19-64$ years & $23,642(54)$ & $7,895(54)$ & $7,875(54)$ & $7,872(54)$ \\
\hline 19-64 years with comorbidities & $12,481(28)$ & $4,146(28)$ & $4,165(28)$ & $4,170(28)$ \\
\hline \multicolumn{5}{|l|}{ Baseline RT-PCR test - n (\%) } \\
\hline Negative & $44,009(100)$ & $14,666(100)$ & $14,676(100)$ & $14,667(100)$ \\
\hline Positive & $22(<0.1)$ & $9(<0.1)$ & $3(<0.1)$ & $10(<0.1)$ \\
\hline \multicolumn{5}{|c|}{ Baseline IgM anti-SARS-CoV-2 rapid test - $\mathrm{n}(\%)$} \\
\hline Negative & $44,013(100)$ & $14,670(100)$ & $14,673(100)$ & $14,670(100)$ \\
\hline Positive & $18(<0.1)$ & $5(<0.1)$ & $6(<0.1)$ & $7(<0.1)$ \\
\hline \multicolumn{5}{|c|}{ Baseline IgG anti-SARS-CoV-2 rapid test - $\mathrm{n}(\%)$} \\
\hline Negative & $43,947(100)$ & $14,644(100)$ & $14,651(100)$ & $14,652(100)$ \\
\hline Positive & $84(0.2)$ & $31(0.2)$ & $28(0.2)$ & $25(0.2)$ \\
\hline
\end{tabular}

${ }^{1}$ Mean (Range) or Frequency (\%)

§Treatment: Placebo; Group A: Two doses of SOBERANA 02, 28 days apart; Group B: Two doses of SOBERANA 02 and 1 dose of SOBERANA PLUS, 28 days apart

*Participants with risk's comorbidities of severe COVID-19 had at least one of these conditions: moderate-tosevere asthma; chronic obstructive pulmonary disease (COPD); cancer; severe obesity (body mass index [the weight in kilograms divided by the square of the height in meters] $\geq 40$ ), cardiovascular disease; diabetes (type 1or type 2); chronic kidney disease (CKD); controlled or uncontrolled high blood pressure (HBP), other immunodeficiency and severe malnutrition. 
medRxiv preprint doi: https://doi.org/10.1101/2021.10.31.21265703; this version posted November 6, 2021. The copyright holder for this preprint (which was not certified by peer review) is the author/funder, who has granted medRxiv a license to display the preprint in

All rights reserved. No reuse allowed without permission.

Figure 2.

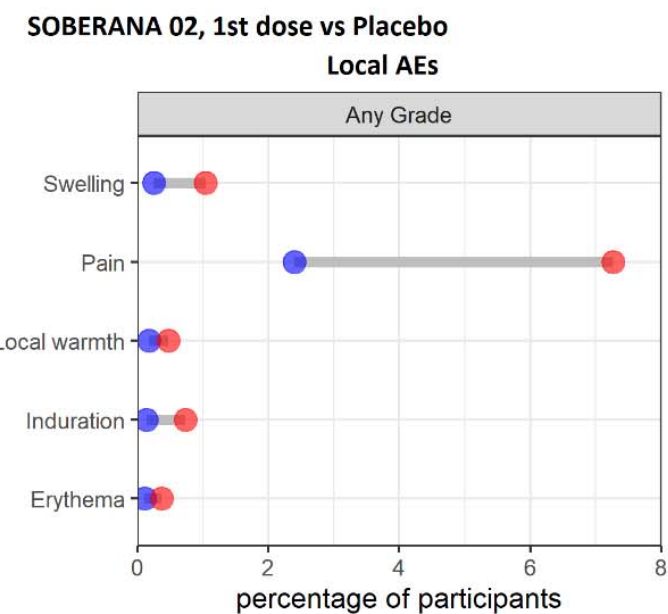

SOBERANA 02, 2nd dose vs Placebo

Local AEs

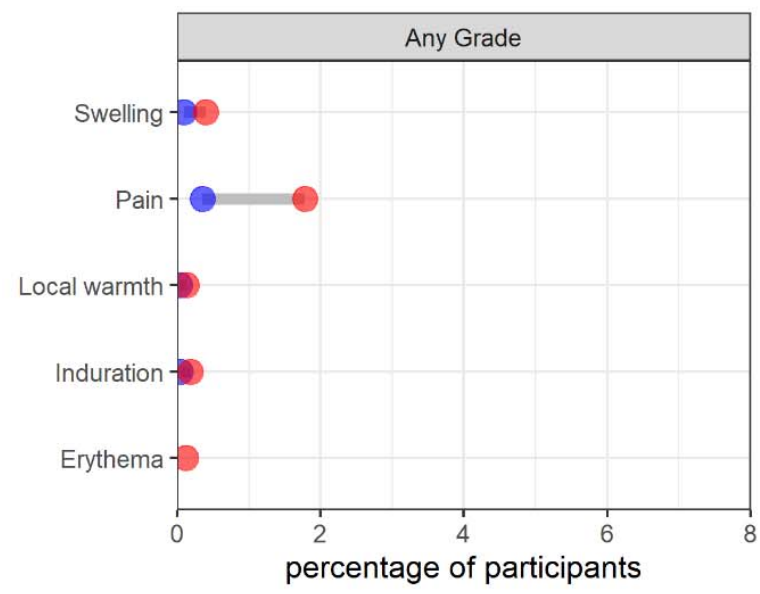

SOBERANA Plus, 3rd dose vs SOBERANA 02

Local AEs

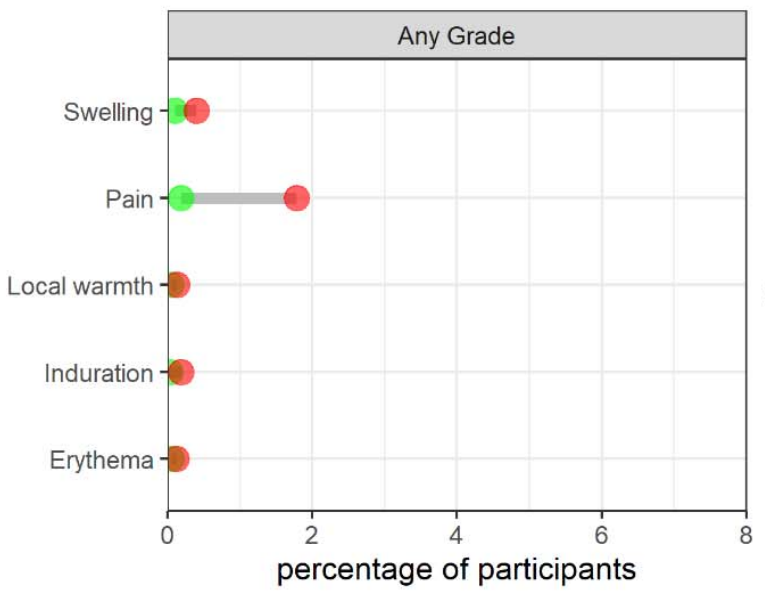

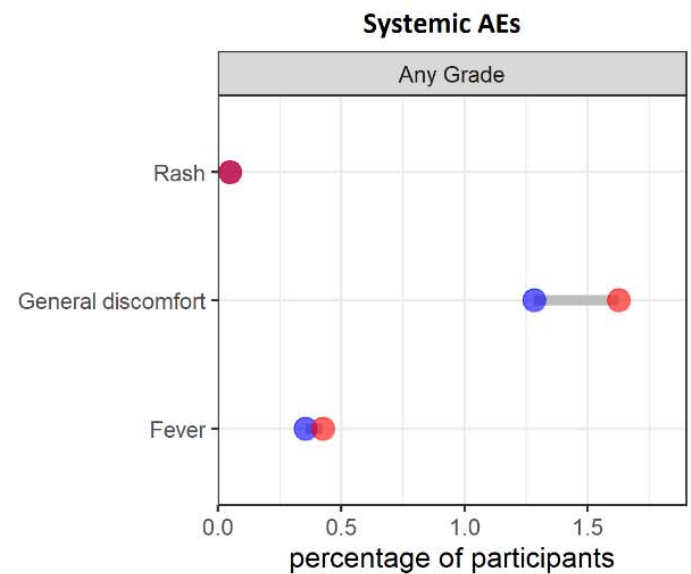

Systemic AEs

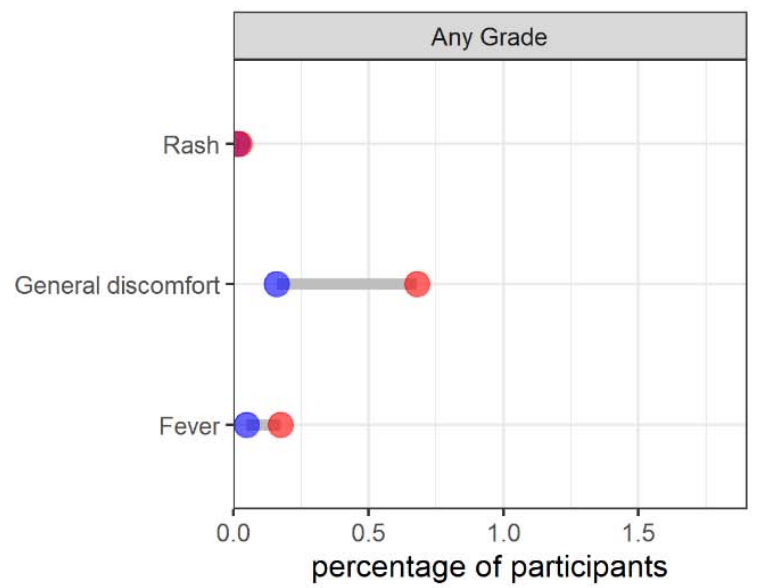

Systemic AEs

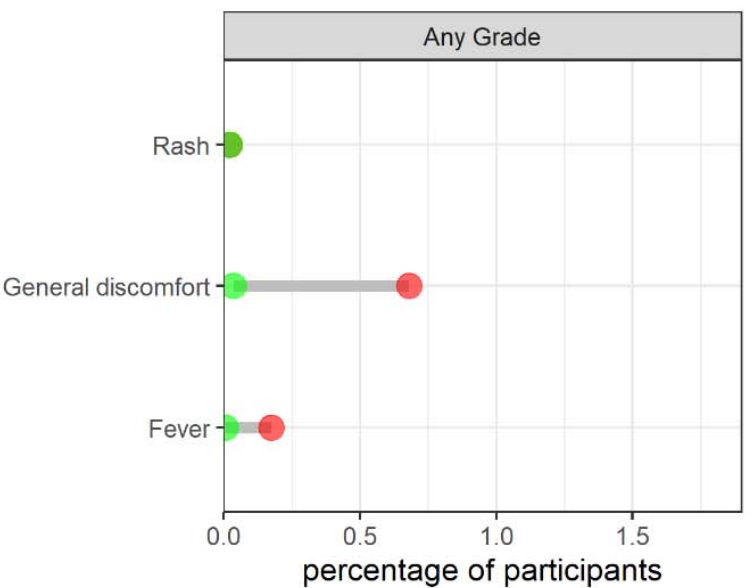


medRxiv preprint doi: https://doi.org/10.1101/2021.10.31.21265703; this version posted November 6, 2021. The copyright holder for this preprint (which was not certified by peer review) is the author/funder, who has granted medRxiv a license to display the preprint in perpetuity.

All rights reserved. No reuse allowed without permission.

Figure 3.

A

Treatment + Placebo + Soberana02

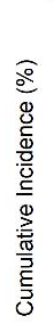

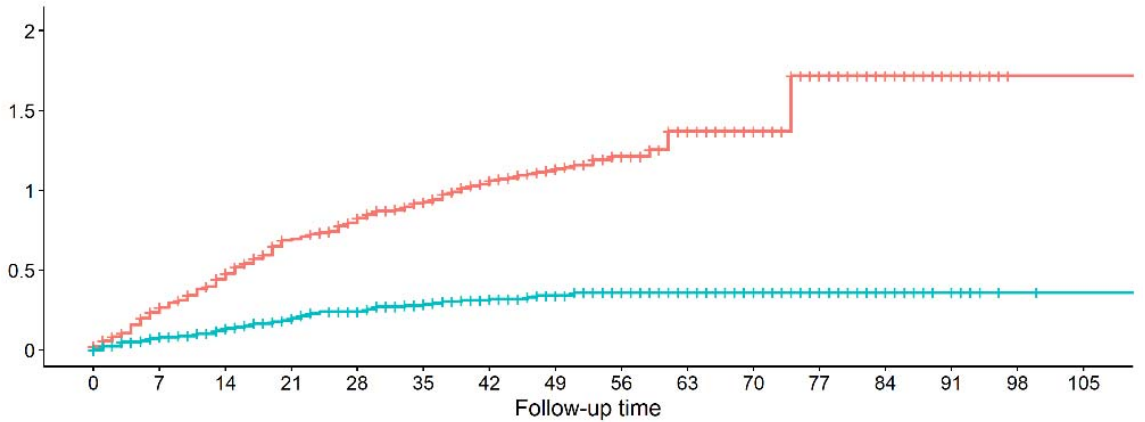

Number at risk

$\begin{array}{rcccccccccccccccc}\text { Placebo } & 14303 & 13031 & 12990 & 12936 & 12896 & 12675 & 12395 & 9445 & 4571 & 1256 & 355 & 240 & 127 & 34 & 1 & 1 \\ \text { Soberana02 } & 14371 & 12575 & 12552 & 12523 & 12489 & 12383 & 11964 & 6777 & 2439 & 373 & 128 & 93 & 53 & 26 & 16 & 15\end{array}$ Number of cases

$\begin{array}{rllllllllllllllll}\text { Placebo } & 3 & 35 & 63 & 91 & 108 & 121 & 138 & 146 & 151 & 154 & 154 & 155 & 155 & 155 & 155 & 155 \\ \text { Soberana02 } & 0 & 10 & 17 & 25 & 30 & 36 & 40 & 42 & 43 & 43 & 43 & 43 & 43 & 43 & 43 & 43\end{array}$

B

Treatment + Placebo + Soberana02+Plus

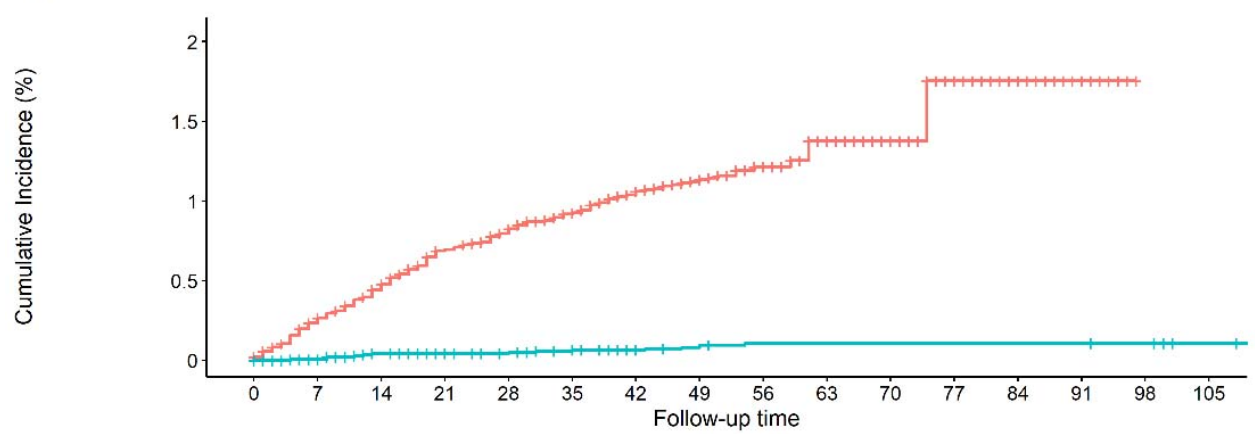

Number at risk

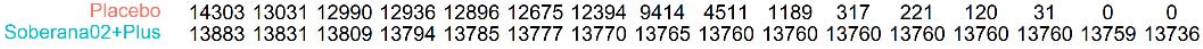
Number of cases

$\begin{array}{rcccccccccccccccc}\text { Placebo } & 3 & 35 & 63 & 91 & 108 & 121 & 138 & 146 & 151 & 154 & 154 & 155 & 155 & 155 & 155 & 155 \\ \text { Soberana02+Plus } & 0 & 1 & 6 & 6 & 7 & 9 & 9 & 13 & 15 & 15 & 15 & 15 & 15 & 15 & 15 & 15\end{array}$ 
medRxiv preprint doi: https://doi.org/10.1101/2021.10.31.21265703; this version posted November 6, 2021. The copyright holder for this preprint (which was not certified by peer review) is the author/funder, who has granted medRxiv a license to display the preprint in perpetuity.

All rights reserved. No reuse allowed without permission.

Figure 4.

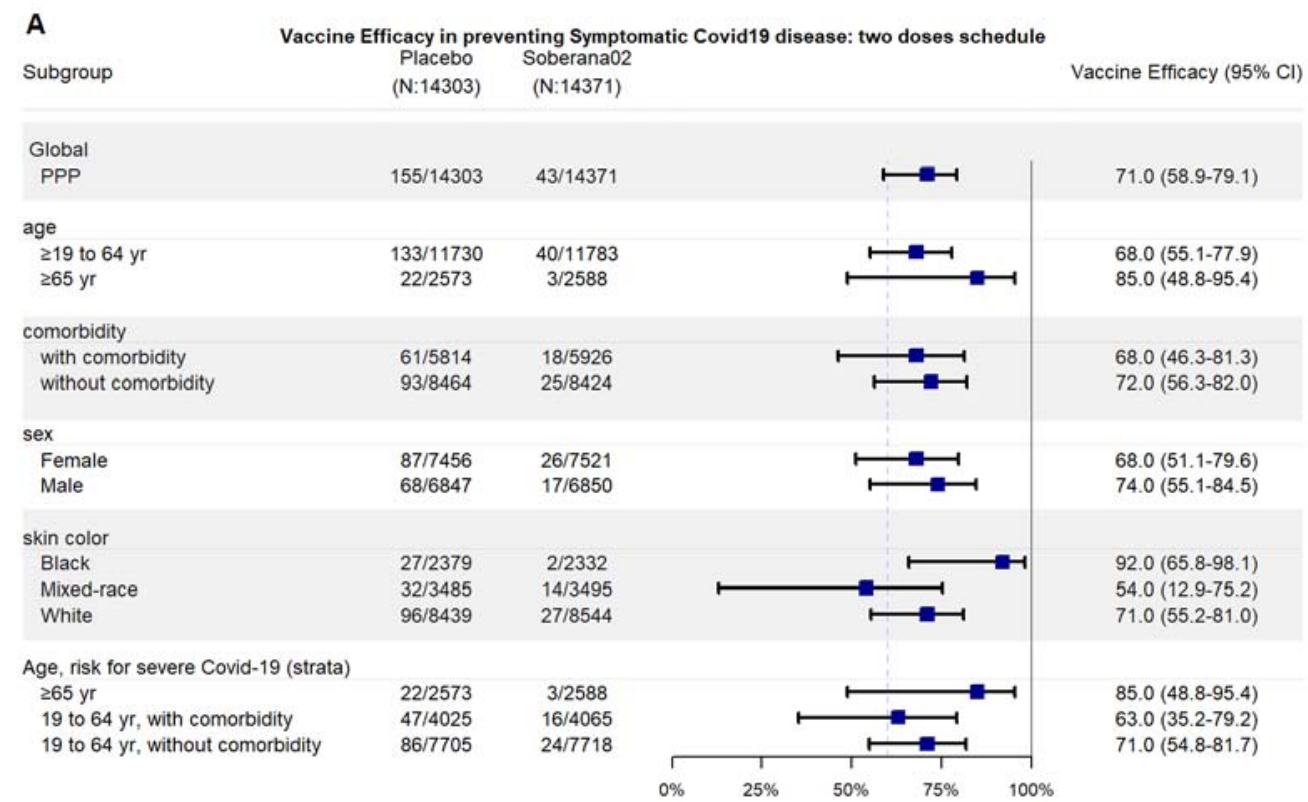

B

Subgroup

Global

PP

age

$\geq 19$ to $64 \mathrm{yr}$

$\geq 65 \mathrm{yr}$

comorbidity

with comorbidity

without comorbidity

Female

Male

skin color

Black

Mixed-race

White

Age, risk for severe Covid-19 (strata)

$265 \mathrm{yr}$

19 to $64 \mathrm{yr}$, with comorbidity

19 to $64 \mathrm{yr}$, without comorbidity
Vaccine Efficacy in preventing Symptomatic Covid19 disease: three doses schedule Placebo Soberana02+PLUS (N:14303) (N:13883)

Vaccine Efficacy $(95 \% \mathrm{Cl})$

$92.4(86.9-95.6)$

$93.8(88.2-96.7)$ $83.4(51.7-94.3)$

$88.7(76.6-94.6)$

$94.8(87.9-97.7)$

$90.2(81.5-94.8)$

$95.5(86.9-98.4)$

93.7 (75. 3-98.4)

$81.3(57.6-91.8)$

$95.8(89.5-98.3)$

83.4 (51.7-94.3)

$91.0(77.8-96.4)$

$95.3(88.4-98.1)$ 
medRxiv preprint doi: https://doi.org/10.1101/2021.10.31.21265703; this version posted November 6,2021 . The copyright holder for this preprint (which was not certified by peer review) is the author/funder, who has granted medRxiv a license to display the preprint in

All rights reserved. No reuse allowed without permission.

\section{Captions}

\section{Figure 1. Enrollment and Outcomes.}

$\S$ Safety population included all the participants who had undergone randomization and received at least one dose of the SOBERANA 02 vaccine or placebo. For SOBERANA 02, two-dose schedule efficacy was measure for individuals receiving both doses of vaccine or placebo. For SOBERANA 02 + SOBERANA Plus, three-dose heterologous schedule efficacy considered individuals receiving the planned three doses or two doses of placebo The primary end point was analyzed in the per-protocol population (PPP)* which included participants who were seronegative at baseline, had no major protocol deviations and were not confirmed as positive COVID19 before day 14 after the last dose (considered as Time 0 for follow-up) Footnote: §Exclusion criteria: acute infection disease on previous 7 days, mental disorders, known history of COVID-19, history of hypersensitivity to components of the formulations, tetanus toxoid vaccine in the last 3 months, previous SARS-CoV-2 vaccine, any immunomodulatory therapy in the last month, pregnancy, puerperium or breastfeeding, uncontrolled chronic diseases, HIV, unstabilized malignant disease or under chemotherapy and/or radiotherapy. *"Lost of follow-up" and "discontinued intervention" were not excluded from the analysis

\section{Figure 2. Solicited Local and Systemic Adverse Events.}

The percentage of participants with solicited local and systemic AEs during the 7 days after each vaccination (any grade: mild, moderate, severe) compared by treatment: $1^{\text {st }}$ and $2^{\text {nd }}$ dose SOBERANA $02 \bigcirc$ vs Placebo $; 3^{\text {rd }}$ dose SOBERANA Plus Ovs Soberana 02 (average from $1^{\text {st }}$ and $2^{\text {nd }}$ dose)

\section{Figure 3. Cumulative Incidence of Symptomatic COVID-19 in the Per-Protocol}

Population. The timing of surveillance for symptomatic COVID-19 began on day 14 after the last dose (marked as Time 0 in figures) in the per-protocol population ) through approximately the first 3 months of follow-up. 
medRxiv preprint doi: https://doi.org/10.1101/2021.10.31.21265703; this version posted November 6, 2021. The copyright holder for this preprint (which was not certified by peer review) is the author/funder, who has granted medRxiv a license to display the preprint in All rights reserved. No reuse allowed without permission.

Figure 4. Vaccine Efficacy of SOBERANA 02 in specific subgroups in the Per-

Protocol Population. A) two-dose schedule, SOBERANA 02; B) Heterologous three-dose schedule (2 x SOBERANA 02 + SOBERANA Plus). Vaccine Efficacy is defined as 1 minus the relative risk (full regime (A or B) vs. placebo). Risk strata (19-64 years without risk comorbidities, 19-64 years with risk comorbidities and $\geq 65$ years). Participants at risk of severe COVID-19 disease were defined in the protocol (available as Supplementary Information) 